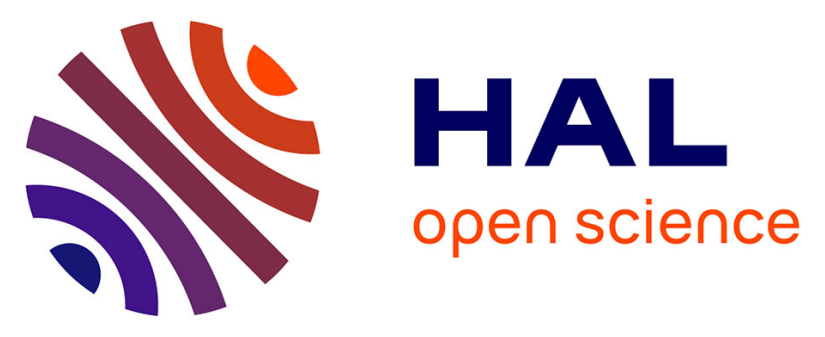

\title{
Constitution of a catchment virtual observatory for sharing flow and transport models outputs
}

Zahra Thomas, Pauline Rousseau-Gueutin, Tamara Kolbe, Benjamin W. Abbott, Jean Marçais, Stefan Peiffer, Sven Frei, Kevin Bishop, Pascal Pichelin, Gilles Pinay, et al.

\section{To cite this version:}

Zahra Thomas, Pauline Rousseau-Gueutin, Tamara Kolbe, Benjamin W. Abbott, Jean Marçais, et al. Constitution of a catchment virtual observatory for sharing flow and transport models outputs. Journal of Hydrology, 2016, RESIDENCE TIMES IN SUBSURFACE HYDROLOGICAL SYSTEMS: Signature of hydrological processes and impact on environmental applications, 543 (Part A), pp.59-66. 10.1016/j.jhydrol.2016.04.067 . insu-01312759

\section{HAL Id: insu-01312759 \\ https://hal-insu.archives-ouvertes.fr/insu-01312759}

Submitted on 9 May 2016

HAL is a multi-disciplinary open access archive for the deposit and dissemination of scientific research documents, whether they are published or not. The documents may come from teaching and research institutions in France or abroad, or from public or private research centers.
L'archive ouverte pluridisciplinaire HAL, est destinée au dépôt et à la diffusion de documents scientifiques de niveau recherche, publiés ou non, émanant des établissements d'enseignement et de recherche français ou étrangers, des laboratoires publics ou privés. 


\section{Accepted Manuscript}

Constitution of a catchment virtual observatory for sharing flow and transport models outputs

Zahra Thomas, Pauline Rousseau-Gueutin, Tamara Kolbe, Benjamin W.

Abbott, Jean Marçais, Stefan Peiffer, Sven Frei, Kevin Bishop, Pascal Pichelin,

Gilles Pinay, Jean-Raynald de Dreuzy

PII:

S0022-1694(16)30260-8

DOI: http://dx.doi.org/10.1016/j.jhydrol.2016.04.067

Reference: $\quad$ HYDROL 21237

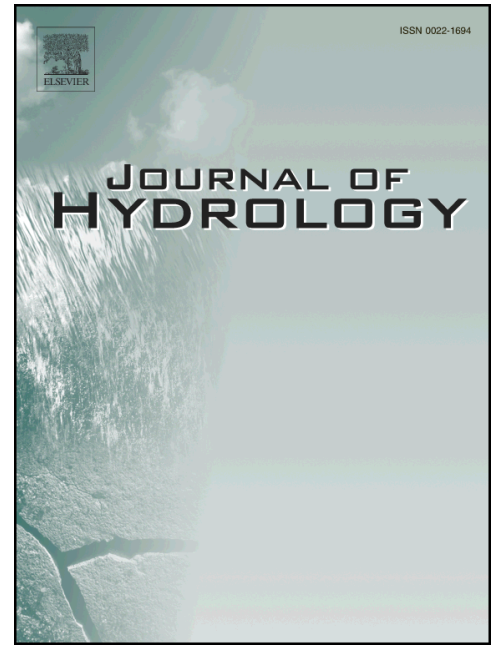

To appear in:

Journal of Hydrology

Please cite this article as: Thomas, Z., Rousseau-Gueutin, P., Kolbe, T., Abbott, B.W., Marçais, J., Peiffer, S., Frei, S., Bishop, K., Pichelin, P., Pinay, G., de Dreuzy, J-R., Constitution of a catchment virtual observatory for sharing flow and transport models outputs, Journal of Hydrology (2016), doi: http://dx.doi.org/10.1016/j.jhydrol. 2016.04.067

This is a PDF file of an unedited manuscript that has been accepted for publication. As a service to our customers we are providing this early version of the manuscript. The manuscript will undergo copyediting, typesetting, and review of the resulting proof before it is published in its final form. Please note that during the production process errors may be discovered which could affect the content, and all legal disclaimers that apply to the journal pertain. 
Constitution of a catchment virtual observatory for sharing flow and transport models outputs

Zahra Thomas ${ }^{1, *}$, Pauline Rousseau-Gueutin ${ }^{2}$, Tamara Kolbe ${ }^{3,4}$, Benjamin W. Abbott $^{4}$, Jean Marçais $^{3}$, Stefan Peiffer ${ }^{5}$, Sven Frei ${ }^{5}$, Kevin Bishop ${ }^{6}$, Pascal Pichelin ${ }^{1}$, Gilles Pinay ${ }^{4}$, JeanRaynald de Dreuzy ${ }^{3}$

${ }^{1}$ AGROCAMPUS OUEST, UMR1069, Soil Agro and hydroSystem, 35000 Rennes, France ${ }^{2}$ EHESP Rennes, Sorbonne Paris Cité, Paris, France

${ }^{3}$ Géosciences Rennes, UMR 6118 CNRS, Université de Rennes 1, Campus de Beaulieu, 35042 Rennes Cedex, France

${ }^{4}$ ECOBIO, OSUR, CNRS, Université de Rennes 1, Campus de Beaulieu, 35042 Rennes, France

${ }^{5}$ Bayreuth Center of Ecology and Environmental Research

${ }^{6}$ Department of Earth Sciences, Uppsala University, Uppsala, Sweden

*Corresponding author.: zthomas@agrocampus-ouest.fr 


\section{Abstract}

Predicting hydrological catchment behaviour based on measurable (and preferably widely available) catchment characteristics has been one of the main goals of hydrological modelling. Residence time distributions provide synoptic information about catchment functioning and can be useful metrics to predict their behaviours. Moreover, residence time distributions highlight a wide range of characteristic scales (spatial and temporal) and mixing processes. However, catchment-specific heterogeneity means that the link between residence time distributions and catchment characteristics is complex. Investigating this link for a wide range of catchments could reveal the role of topography, geology, land-use, climate and other factors in controlling catchment hydrology. Meaningful comparison is often challenging given the diversity of data and model structures and formats. To address this need, we are introducing a new virtual platform called Catchment virtual Observatory for Sharing flow and transport models outputs (COnSOrT). The goal of COnSOrT is to promote catchment intercomparison by sharing calibrated model outputs. Compiling commensurable results in COnSOrT will help evaluate model performance, quantify inter-catchment controls on hydrology, and identify research gaps and priorities in catchment science. Researchers interested in sharing or using calibrated model results are invited to participate in the virtual observatory. Participants may test post-processing methods on a wide range of catchment environments to evaluate the generality of their findings.

Keywords : transit time distribution, modelling outputs, catchment hydrology, biogeochemistry, watershed, inter-catchment comparison 


\section{Introduction}

Predicting hydrological catchment behaviour based on measurable (and preferably widely available) catchment characteristics has been one of the main goals of hydrological modelling since the founding of the field over 150 years ago (Mulvany 1850 in Todini, 2007). Many studies have used topography, geology, land-use, and climate to develop models that can be applied to both gauged and ungauged basins (e.g. Blöschl et al., 2013; Sivapalan, 2003; Soulsby and Tetzlaff, 2008). Technical and theoretical advances in catchment hydrology, including the recent proliferation of commercial and open-source modelling software, have led to a rich diversity of detailed, catchment-specific modelling studies (Beven et al., 2012; Beven and Alcock, 2012; Benettin et al., 2015; Endalamaw et al., 2013; Laudon et al., 2013; Leray et al., 2012; Morton et al., 2014). However, many models have specific, sometimes proprietary data output formats such as MODFLOW, FEFLOW, HydroGeoSphere and other prominent platforms, hindering inter-catchment comparisons and leaving fundamental questions of catchment functioning unanswered. Inter-catchment comparisons remain rare (McGuire et al., 2005; Tetzlaff et al., 2009b), evidence of how challenging it can be to develop general models or approaches applicable for multiple gauged and ungauged catchments.

The mean transit time and whole stream residence time distribution are powerful metrics of catchment functioning, providing synoptic hydrological information such as water renewal time, heterogeneity of flowpaths, and overall water volume (Godsey et al., 2010; Hrachowitz et al., 2010; Marçais et al., 2015; McGuire and McDonnell, 2006; Van der Velde et al., 2012)

. These hydrological parameters influence catchment biogeochemistry (Ocampo et al., 2006; Oldham et al., 2013; Pinay et al., 2015; Tetzlaff et al., 2007), further increasing their value as 
indicators and predictors of catchment-scale water quality and chemistry. Because these parameters are of great general interest they feature prominently in the inputs and outputs of many models (e.g. McGuire et al., 2005; Tetzlaff et al., 2009a). In combination with generic model results such as flow lines or path lines, residence time distributions represent a potential tool to compare a wide variety of models and model types from different climatic, topographic and hydrogeological contexts. Such tools may help to bring out general approaches for inter-catchment comparison.

To facilitate the comparison and improvement of hydrological models and general understanding of hydrological behaviour at the catchment scale, we have created a working group and repository for researchers to share metadata and calibrated model outputs. This virtual observatory called Catchment virtual Observatory for Sharing flow and transport models outputs (COnSOrT) provides a platform to compare catchment response and to extensively test modelling approaches (frameworks, post-processing, lumped etc.). Our main objective is to collect model outputs from small catchments in differing geological and hydrological conditions to identify controls on biogeochemical and hydrologic functioning in a standardized way that allows direct comparison of model out puts. We are proposing that RTDs and their parameterization are a global platform to characterize and compare catchments. To these ends we are proposing to establish a virtual observatory that will allow testing of research questions that are difficult to address individually including: i) How do topography and geomorphology influence hydrology across catchments, ii) What modelling concepts and approaches perform best across catchments, and iii) What are the relevant metrics of catchment vulnerability in regards to contaminant transport or removal for different degrees of anthropogenic disturbance? Below we outline the initial rationale for COnSOrT, 
describe the general data structure, and give an example showing how outputs from different modelling platforms can be synthesized.

\section{Time distributions as a comparable metric of catchment hydrology}

\subsection{Starting with small catchments and groundwater flow cells}

While the ultimate goal of COnSOrT and catchment hydrology in general is to understand the mechanisms regulating hydrological functioning across spatiotemporal scales, there are several reasons why it makes sense to start small. All waterways, surface or subsurface, start in small catchments. Headwater catchments are typically defined as watersheds smaller than $100 \mathrm{~km}^{2}$, though this definition is strictly operational and cut-offs ranging from $0.1 \mathrm{~km}^{2}$ to over $100 \mathrm{~km}^{2}$ can be found in the literature (Buttle, 1998; Maher, 2011; Moldan and Černỳ, 1994; Tetzlaff et al., 2008). Headwater catchments occupy an influential position in the landscape (Jones et al., 2005), they are a major component of controlling groundwater recharge and overall water residence time (Alexander et al., 2007), and they make up the bulk of global lotic ecosystems, with $90 \%$ of stream length occurring in catchments smaller than 15 $\mathrm{km}^{2}$ (Bishop et al., 2008). Small catchments express a wide diversity of subsurface flow configurations (Eberts et al., 2012; Gburek and Folmar, 1999; Sophocleous, 2002; Winter, 1999) depending on geological and topographical structures, distribution and timing of recharge, characteristics of the vadose zone, and free surface dynamics of the underlying aquifer (Bresciani et al., 2014; Schumann et al., 2010; Freer et al., 2002; Montgomery and Dietrich, 1989; O’loughlin, 1981; Šimŭnek et al., 2003; Voeckler et al., 2014; Dages et al., 2009; de Vries and Simmers, 2002; Scanlon et al., 2002). 
Perhaps most importantly in regards to catchment hydrology, small catchments are a convenient and powerful experimental unit. Compared to large catchments, there are fewer processes influencing behaviour of small catchments and collecting detailed biogeochemical and hydrological data is more feasible at a small scale. It is also easier to find multiple, nearby catchments with similar climate and environmental contexts, or conversely catchments with distinct characteristics such as fertilization, harvest, or natural disturbance regimes, allowing the identification of controls on catchment functioning. While the great diversity of small catchment behaviour complicates predictions for ungauged catchments and the regionalization of models based on well-monitored sites (Hrachowitz et al., 2013; Schilling et al., 2013; Tetzlaff et al., 2010), it emphasizes the importance of inter-catchment comparisons to validate model operation and to remove site-specific relationships. Substantial unknowns persist about the functioning of small catchments, representing a major gap in our understanding of hydrological and biogeochemical functioning of coupled aquatic and terrestrial ecosystems (Bishop et al., 2008; Cole et al., 2007; Karlsen et al., 2015). The growing abundance of small catchment studies in multiple biomes and ecosystem represents an opportunity to address these uncertainties (Benettin et al., 2015; Bormann and Likens, 1994; Jones et al., 2005; Laudon et al., 2011; Likens, 2013; Swank and Crossley, 1988).

Understanding the organization of groundwater flows has been in the center of many researches. Tóth (1963) developed a conceptual model in which under a hummocky water table, groundwater flows are distributed into local, sub-local and regional flows. Numerous studies have used this theory (e.g. Cardenas, 2007; Goderniaux et al., 2013) in order to understand groundwater flows at the regional scale (nested catchment scale). Those studies emphasize the relation between the topography and the geology to control the regional, sub- 
local and local flows (e.g., Haitjema and Mitchell, 2005; Freeze and Witherspoon, 1967). The time distribution has been used in those regional studies in order to identify relationship between the time distribution and the nested flow organization (e.g. Kolbe et al., this issue; Eberts et al., 2012).

\subsection{Time distribution terms and concepts}

The amount of time water remains in a catchment is one of the key parameters controlling biogeochemical functioning and can vary in small catchments from a few days to millennia (McDonnell and Beven, 2014; Moldan and Černỳ, 1994; Rodhe et al., 1996; Frisbee et al., 2013). The mean transit time, or the average amount of time a water molecule stays within the watershed boundaries, is an integrated measure of catchment residence time (e.g. Capell et al., 2012; McGuire et al., 2002; Soulsby and Tetzlaff, 2008). Transit and residence times are two common metrics of how long water stays in a system. Transit time is defined as the time that water takes to reach the outlet of a system, whereas the residence time is the time since water entered the system calculated at any sampling location of interest (McGuire and McDonnell, 2006). Because these measures are analogous for our purposes, we will hereafter refer to their distributions as travel time distributions. The realization that catchment travel time distributions are usually very skewed with long tails (Kirchner et al., 2001) has focused recent analysis on the whole travel time distribution (Dunn et al., 2010).

As it is impractical to measure the whole travel time distribution using injected hydrological tracers (but see Rodhe et al., 1996), different approaches, such as lumped parameter models, particle-tracking, and direct age simulation, have been developed to estimate travel time distributions (Turnadge and Smerdon, 2014). Several distribution types have been used in catchment studies, including the dispersion model (Kirchner et al., 2001; McGlynn et al., 
2003; McGuire et al., 2002), the piston flow model (McGlynn et al., 2003), and exponentialpiston flow (Maloszewski and Zuber, 1996; McGlynn et al., 2003; McGuire et al., 2002; Timbe et al., 2014). The exponential distribution has been the most widely used (more than $60 \%$ of the studies in several recent reviews; McGuire and McDonnell, 2006; Mueller et al., 2013; Roa-Garcia and Weiler, 2010; Seeger and Weiler, 2014), though more recently, the gamma function has been recognized as more conceptually and mathematically suitable to represent catchment behaviour and mixing processes due to its short breakthrough time and long tail (Birkel et al., 2012; Dunn et al., 2010; Heidbüchel et al., 2012; Hrachowitz, 2011; Hrachowitz et al., 2010; Kirchner et al., 2001, 2000; Soulsby et al., 2011).

\subsection{Controls on time distributions}

Topography is one of the main controls of groundwater flow (e.g., Haitjema, 1995; Tóth, 1962) and topographic indices are often correlated with stream travel time distribution or mean residence time (McGuire et al., 2005; Tetzlaff et al., 2009a). For example, a positive correlation between the ratio of flowpath distance to flowpath gradient and the stream mean residence time has proven to be robust in an inter-comparison of seven catchments of differing size, geology, and climate (McGuire et al., 2005). In a comparison of 8 catchments and 55 sub-catchments, in diverse geomorphic provinces, the inverse transit time proxy (a ratio of the variability of $\delta^{18} \mathrm{O}$ in stream water compared with the variability in precipitations) was correlated to various topographic indices such as elevation above stream, distance from the stream, average gradient along the flowpath to the stream, ratio of flowpath length and gradient, though these correlations varied by geomorphic province (Tetzlaff et al., 2009a). In general, topography appears to play a greater role in controling transit time high-relief catchments (e.g. mountainous catchments) compared to flatter catchments, though soil 
characteristics can modulate the effect of topography on hydrological function (Hrachowitz et al., 2009; Rodgers et al., 2005; Tetzlaff et al., 2009a).

Geological setting and more particularly the heterogeneity of hydraulic conductivity has a strong influence on the organisation of groundwater flow systems and consequently on time distribution (Ameli et al., submitted; Cardenas and Jiang, 2010; Freeze and Witherspoon, 1967; Haitjema, 1995; Jiang et al., 2009; Vitvar and Balderer, 1998; Viville et al., 2006). In unconfined aquifers with unconsolidated materials, the vertical profile of saturated hydraulic conductivity influences the shape of the travel time distribution. Strong vertical decreases in hydraulic conductivity were associated with more dispersed travel time distributions (Ameli et al., submitted). There is no clear relationship between catchment size and travel time distribution, with some studies finding a correlation (McDonnell et al., 1999; Soulsby et al., 2011; Wolock et al., 1997) but others finding no correlation (McGlynn et al., 2003; McGuire et al., 2005, 2002).

\subsection{Temporal variability}

Most studies assume that travel time distributions are time invariant, with no seasonal or interannual changes in the overall volume of stored water (Harman, 2015) and relatively short residence times (Van der Velde et al., 2012). Such steady-state systems are described with a single travel time distribution (Heidbüchel et al., 2012). While this simplification may realistically represent some humid catchments, in most environments, seasonally and event driven variations in precipitation and evapotranspiration can violate this assumption, leading to time-variant time distributions (Heidbüchel et al., 2012; Hrachowitz et al., 2010; Rinaldo et al., 2011; Van der Velde et al., 2015). In addition to low-frequency changes such as seasonal or climatic change, antecedent catchment wetness can vary between events, influencing time 
distributions at a weekly scale (Birkel et al., 2011; Hrachowitz et al., 2009), and variation in the contribution of old and young water to the outlet can occur during a single event (Harman, 2015). In summary, travel time distributions characterize multi-scale and multi-process transport mechanisms in surface and subsurface systems, which vary in time and space (Eberts et al., 2012). These processes are controlled by natural factors such as topography, land cover, hydraulic properties, and low frequency forcing as well as by human disturbance such as water redistribution, land use, and alteration of surface permeability (Fig. 1). We propose that the comparison of travel time from catchments from differing biomes could lead to a more systematic understanding of catchment behaviour and general theory. Because biogeochemistry is tightly linked to residence time, a better understanding of the travel time distributions will improve the assessment of nutrient removal capacity (Pinay et al., 2015), climate change impacts on stream chemistry (Abbott et al., 2015; Goode, 1996; McGuire et al., 2005) and exposure time (Ginn, 1999; Frei et al., this issue; Oldham et al., 2013).

\section{The catchment virtual observatory COnSOrT}

There is a movement in many disciplines, to create globally accessible databases and datasharing structures. In hydrology this movement is particularly strong (Hrachowitz et al., 2013) with efforts including the Experimental Hydrology WIKI (www.experimental-hydrology.net), the Distributed Model Intercomparison Project Phase 2 (http://www.nws.noaa.gov/oh/hrl/dmip/2/), the open GEOSPATIAL Consortium (www.opengeospatial.org), and CUAHSI HIS (http://his.cuahsi.org/). These efforts are assembling valuable model outputs, however, most calibrated numerical model outputs are still not shared, despite the substantial benefits discussed previously. The purpose of COnSOrT is to host, at least at the beginning, pathlines from calibrated groundwater models 
from a wide range of environments. This will allow the comparison of RTD at different sites in order to generalize findings on a wide range of catchments. Also, post-processing methods will be available on the platform.

\subsection{The need for COnSOrT}

The COnSOrT virtual platform provides benefits for modelers and field researchers. The observatory will allow the testing of models in a wide range of catchment environments to evaluate model generality with consistent post-processing methods. For example, Marçais et al. (2015) used lumped parameter models to infer the residence time distribution at the Ploemeur research site in western France. They used modeling and environmental tracers to study groundwater flow at the catchment scale. They found that two-parameter distributions are suitable to assess and predict the hydrodynamic behaviour of the catchment. This suggests that with only two environmental tracers (e.g. $\mathrm{Cl}^{-}, \mathrm{F}-, \mathrm{CFC}, \mathrm{SF} 6$, or $\left.\mathrm{Kr} 85\right)$, it would be possible to assess catchment behaviour from a theoretical time distribution and make predictions as to how the catchment would respond to different hydrological conditions. But is this conclusion a consequence of site particularities or is the model more broadly applicable? Similarly, Laudon et al. (2011) analysed the controls on DOC concentration in boreal streams. They found that DOC was mainly controlled by landscape type (i.e. forest or wetland) and by the connectivity between the different areas of the catchment. They concluded that DOC concentration along the stream can be explained using a two-component mixing model with contributions from two homogeneous headwater catchments. As for the previous example, it is difficult to assess if this conclusion is site-specific or if it is general without comparison with other sites. We expect that time distribution obtained from the pathlines of a calibrated model can help to understand the nested catchments connectivity. 
The analysis of different models from a wide range of environments and hydrogeologic contexts could methodically address this kind of recurring question. Another benefit of the observatory is that scientists with calibrated numerical models can use the post-processing methods as a complementary approach to analysing their data. Field scientists with water chemistry time series for a watershed could invite modelers associated with the observatory to test their models against observed catchment behaviour, building the observatory and improving general understanding of small-catchment hydrology.

\subsection{Organisation}

In this section we would like to introduce you to the online platform (http://geowww.agrocampus-ouest.fr/smallcatchmentsvirtualobservatory/index.html) and present the general organisation and the procedure to submit and retrieve results. Currently, only particle path files are being accepted as output files, but as the observatory grows in the near future we will accept more outputs, such as concentration field files and other outputs. If you have a suggestion for a file type or possible comparison, please contact us. We chose to start with particle path files because they are quite generic and can be produced by many hydrological modelling packages (e.g. MODFLOW/PMPATH/MODPATH, FEFLOW, Hydrogeosphere, H2OLAB). Any file format can be used for the particle path file (e.g. xlsx, csv, txt etc.) as long as it is described. In order to be compatible with the software, the pathlines file should at least contain the following fields: $\mathrm{X}, \mathrm{Y}$, and $\mathrm{Z}$ coordinates, the time, and the particle number. In addition to the data file itself, metadata such as location, topographic information, and hydrology are required. We also ask for helpful information about model parametrization (e.g. geometry of flow domain, initial and boundary conditions, etc.), calibration, and validation methodology (Fig. 2). Table 1 summarizes metadata available 
on the website for an example catchment "Le Guyout," which is a small catchment situated in Brittany at the LTER Zone Atelier Armorique (Thomas et al., 2015). For this small catchment, flow domain topography as well as subsurface geometry structure (Fig. 3) were constructed from a 2m-resolution Lidar digital elevation model and geologic data. The FEFLOW numerical model was used to obtain velocity field, flowpaths, and pathlines. Fig. 4 and Fig. 5 show the particle path file and histogram of the residence time distribution, respectively, obtained and shared on the platform. In addition to model outputs, metadata inputs and post-processing methods (.exe files or open-source program codes) will be available on the platform. The repository of all documents and files will be maintained by the Observatoire des Sciences de l'Univers à Rennes (OSUR) (Fig. 2).

\subsection{How to get involved?}

All researchers interested in sharing their model outputs or contributing to new analyses or comparisons are invited to contribute and participate with COnSOrT. There is a simple process on the website providing a username and institution information which allows users to upload and control access of their data and metadata files. No login is required to download files and post-processings methods available on the platform.

\section{Conclusion}

One of the main goals in catchment hydrology is to generate theoretical frameworks that accurately reflect processes and behaviours, which can reliably be applied to numerous catchments. Eventually, these frameworks may be used to describe ungauged catchment behaviour from easily measurable parameters or characteristics. We invite you to join us in working towards this goal by participating in this new virtual observatory. COnSOrT collects outputs from calibrated groundwater models and observed metadata. There are numerous 
benefits of COnSOrT including the opportunity to perform large (worldwide) inter-catchment comparisons. Another major benefit is the sharing of new approaches to interpret model outputs. There are numerous ways to get involved including contributing model outputs or observations and testing the post-processing methods on a wide range of catchment environments to evaluate the generality of their findings. There is already a growing group of committed COnSOrT members but the value of these model outputs and catchment information increases with each new researcher that gets involved. We hope you will bring your expertise to the table to participate in this exciting opportunity to push forward our understanding of small catchment science.

\section{Acknowledgments}

Financial support for this research was provided by the European Union's Seventh Framework for research, technological development and demonstration under grant agreement no. 607150. The authors are grateful to the Marie Curie Actions for funding this research. This paper was supported by the European Union International Training Network "INTERFACES: Ecohydrological interfaces as critical hotspots for transformations of ecosystem exchange fluxes and biogeochemical cycling'. We also thank the LTER Zone Atelier Armorique. The authors acknowledge DHI for sponsoring the license for the MIKE Powered by DHI Software - FEFLOW. 


\section{REFERENCES}

Abbott, B. W., Jones, J. B., Godsey, S. E., Larouche, J. R. and Bowden, W. B.: Patterns and persistence of hydrologic carbon and nutrient export from collapsing upland permafrost, Biogeosciences, 12(12), 3725-3740, doi:10.5194/bg-12-3725-2015, 2015.

Alexander, R.B., Boyer, E.W., Smith, R.A., Schwarz, G.E., Moore, R.B., 2007. The Role of Headwater Streams in Downstream Water Quality. J. Am. Water Resour. Assoc. 43, 41-59. doi:10.1111/j.1752-1688.2007.00005.x

Ameli, A.A., McDonnell, J.J., Bishop, K., submitted. The exponential decline in saturated hydraulic conductivity with depth: A novel method for exploring its effect on water flow paths and transit time distribution. Submitt. Hydrol. Process.

Benettin, P., Kirchner, J.W., Rinaldo, A., Botter, G., 2015. Modeling chloride transport using travel time distributions at Plynlimon, Wales. Water Resour. Res. 51, 3259-3276. doi:10.1002/2014WR016600

Beven, K., Buytaert, W., Smith, L.A., 2012. On virtual observatories and modelled realities (or why discharge must be treated as a virtual variable). Hydrol. Process. 26, 19051908. doi:10.1002/hyp.9261

Beven, K.J., Alcock, R.E., 2012. Modelling everything everywhere: a new approach to decision-making for water management under uncertainty. Freshw. Biol. 57, 124-132. doi:10.1111/j.1365-2427.2011.02592.x

Birkel, C., Soulsby, C., Tetzlaff, D., 2011. Modelling catchment-scale water storage dynamics: reconciling dynamic storage with tracer inferred passive storage. Hydrol. Process. 25, 3924. 
Birkel, C., Soulsby, C., Tetzlaff, D., Dunn, S., Spezia, L., 2012. High-frequency storm event isotope sampling reveals time-variant transit time distributions and influence of diurnal cycles. Hydrol. Process. 26, 308-316. doi:10.1002/hyp.8210

Bishop, K., Buffam, I., Erlandsson, M., Fölster, J., Laudon, H., Seibert, J., Temnerud, J., 2008. Aqua Incognita: the unknown headwaters. Hydrol. Process. 22, 1239-1242. doi:10.1002/hyp.7049

Blöschl, G., Sivapalan, M., Wagener, T., 2013. Runoff prediction in ungauged basins: synthesis across processes, places and scales. Cambridge University Press.

Bormann, F.H., Likens, G., 1994. Pattern and process in a forested ecosystem: disturbance, development and the steady state based on the Hubbard Brook ecosystem study. Springer Science \& Business Media.

Bresciani, E., Davy, P., de Dreuzy, J.-R., 2014. Is the Dupuit assumption suitable for predicting the groundwater seepage area in hillslopes? Water Resour. Res. 50, 23942406. doi:10.1002/2013WR014284

Buttle, J.M., 1998. Chapter 1 - Fundamentals of Small Catchment Hydrology, in: McDONNELL, C.K.J. (Ed.), Isotope Tracers in Catchment Hydrology. Elsevier, Amsterdam, pp. $1-49$.

Capell, R., Tetzlaff, D., Hartley, A.J., Soulsby, C., 2012. Linking metrics of hydrological function and transit times to landscape controls in a heterogeneous mesoscale catchment. Hydrol. Process. 26, 405-420. doi:10.1002/hyp.8139

Cardenas, M.B., 2007. Potential contribution of topography-driven regional groundwater flow to fractal stream chemistry: Residence time distribution analysis of Tóth flow. Geophysical Research Letters, 34(5). doi: 10.1029/2006gl029126 
Cardenas, M.B., Jiang, X.-W., 2010. Groundwater flow, transport, and residence times through topography-driven basins with exponentially decreasing permeability and porosity. Water Resour. Res. 46, n/a-n/a. doi:10.1029/2010WR009370

Cole, J.J., Prairie, Y.T., Caraco, N.F., McDowell, W.H., Tranvik, L.J., Striegl, R.G., Duarte, C.M., Kortelainen, P., Downing, J.A., Middelburg, J.J., Melack, J., 2007. Plumbing the Global Carbon Cycle: Integrating Inland Waters into the Terrestrial Carbon Budget. Ecosystems 10, 172-185. doi:10.1007/s10021-006-9013-8

Dages, C., Voltz, M., Bsaibes, A., Prévot, L., Huttel, O., Louchart, X., Garnier, F., Negro, S., 2009. Estimating the role of a ditch network in groundwater recharge in a Mediterranean catchment using a water balance approach. J. Hydrol. 375, $498-512$. doi:http://dx.doi.org/10.1016/j.jhydrol.2009.07.002

de Vries, J., Simmers, I., 2002. Groundwater recharge: an overview of processes and challenges. Hydrogeol. J. 10, 5-17. doi:10.1007/s10040-001-0171-7

Dunn, S., Birkel, C., Tetzlaff, D., Soulsby, C., 2010. Transit time distributions of a conceptual model: their characteristics and sensitivities. Hydrol. Process. 24, 1719-1729.

Eberts, S.M., Böhlke, J.K., Kauffman, L.J., Jurgens, B.C., 2012. Comparison of particletracking and lumped-parameter age-distribution models for evaluating vulnerability of production wells to contamination. Hydrogeol. J. 20, 263-282. doi:10.1007/s10040011-0810-6.

Endalamaw, A., Bolton, W., Young, J., Morton, D., Hinzman, L., 2013. Toward Improved Parameterization of a Meso-Scale Hydrologic Model in a Discontinuous Permafrost, Boreal Forest Ecosystem, in: AGU Fall Meeting Abstracts. p. 0549. 
Freer, J., McDonnell, J.J., Beven, K.J., Peters, N.E., Burns, D.A., Hooper, R.P., Aulenbach, B., Kendall, C., 2002. The role of bedrock topography on subsurface storm flow. Water Resour. Res. 38, 5-1-5-16. doi:10.1029/2001WR000872

Freeze, R.A., Witherspoon, P.A., 1967. Theoretical analysis of regional groundwater flow: 2. Effect of water-table configuration and subsurface permeability variation. Water Resour. Res. 3, 623-634. doi:10.1029/WR003i002p00623

Frisbee, M.D., Wilson, J.L., Gomez-Velez, J.D., Phillips, F.M., Campbell, A.R., 2013. Are we missing the tail (and the tale) of residence time distributions in watersheds? Geophys. Res. Lett. 40, 4633-4637. doi:10.1002/grl.50895

Gburek, W.J., Folmar, G.J., 1999. Patterns of contaminant transport in a layered fractured aquifer. J. Contam. Hydrol. 37, 87 - 109. doi:http://dx.doi.org/10.1016/S01697722(98)00158-2

Ginn, T.R., 1999. On the distribution of multicomponent mixtures over generalized exposure time in subsurface flow and reactive transport: Foundations, and formulations for groundwater age, chemical heterogeneity, and biodegradation. Water Resour. Res. 35, 1395-1407. doi:10.1029/1999WR900013

Goderniaux, P., Davy, P., Bresciani, E., de Dreuzy, J.-R., Le Borgne, T., 2013. Partitioning a regional groundwater flow system into shallow local and deep regional flow compartments. Water Resources Research, 49(4): 2274-2286. doi: 10.1002/wrcr.20186

Godsey, S.E., Aas, W., Clair, T.A., de Wit, H.A., Fernandez, I.J., Kahl, J.S., Malcolm, I.A., Neal, C., Neal, M., Nelson, S.J., Norton, S.A., Palucis, M.C., Skjelkvåle, B.L., Soulsby, C., Tetzlaff, D., Kirchner, J.W., 2010. Generality of fractal 1/f scaling in 
catchment tracer time series, and its implications for catchment travel time distributions. Hydrol. Process. 24, 1660-1671. doi:10.1002/hyp.7677

Goode, D.J., 1996. Direct simulation of groundwater age. Water Resour. Res. 32, 289-296.

Haitjema, H.M., 1995. Analytic element modeling of groundwater flow. Academic Press.

Haitjema, H.M., Mitchell-Bruker, S., 2005. Are water tables a subdued replica of the topography? Ground water, 43(6): 781-6. doi: 10.1111/j.1745-6584.2005.00090.x

Harman, C.J., 2015. Time-variable transit time distributions and transport: Theory and application to storage-dependent transport of chloride in a watershed. Water Resour. Res. 51, 1-30. doi:10.1002/2014WR015707

Heidbüchel, I., Troch, P.A., Lyon, S.W., Weiler, M., 2012. The master transit time distribution of variable flow systems. Water Resour. Res. 48, n/a-n/a. doi:10.1029/2011WR011293

Hrachowitz, M., 2011. Sensitivity of mean transit time estimates to model conditioning and data availability. Hydrol. Process. 25, 980.

Hrachowitz, M., Savenije, H.H.G., Blöschl, G., McDonnell, J.J., Sivapalan, M., Pomeroy, J.W., Arheimer, B., Blume, T., Clark, M.P., Ehret, U., Fenicia, F., Freer, J.E., Gelfan, A., Gupta, H.V., Hughes, D.A., Hut, R.W., Montanari, A., Pande, S., Tetzlaff, D., Troch, P.A., Uhlenbrook, S., Wagener, T., Winsemius, H.C., Woods, R.A., Zehe, E., Cudennec, C., 2013. A decade of Predictions in Ungauged Basins (PUB) - a review. Hydrol. Sci. J. 58, 1198-1255. doi:10.1080/02626667.2013.803183

Hrachowitz, M., Soulsby, C., Tetzlaff, D., Dawson, J.J.C., Malcolm, I.A., 2009. Regionalization of transit time estimates in montane catchments by integrating landscape controls. Water Resour. Res. 45, n/a-n/a. doi:10.1029/2008WR007496 
Hrachowitz, M., Soulsby, C., Tetzlaff, D., Malcolm, I.A., Schoups, G., 2010. Gamma distribution models for transit time estimation in catchments: Physical interpretation of parameters and implications for time-variant transit time assessment. Water Resour. Res. 46, n/a-n/a. doi:10.1029/2010WR009148

Jiang, X.-W., Wan, L., Wang, X.-S., Ge, S., Liu, J., 2009. Effect of exponential decay in hydraulic conductivity with depth on regional groundwater flow. Geophys. Res. Lett. 36, n/a-n/a. doi:10.1029/2009GL041251

Jones, J.B., Petrone, K.C., Finlay, J.C., Hinzman, L.D., Bolton, W.R., 2005. Nitrogen loss from watersheds of interior Alaska underlain with discontinuous permafrost. Geophys. Res. Lett. 32, n/a-n/a. doi:10.1029/2004GL021734

Kirchner, J.W., Feng, X., Neal, C., 2001. Catchment-scale advection and dispersion as a mechanism for fractal scaling in stream tracer concentrations. J. Hydrol. 254, $82-$ 101. doi:http://dx.doi.org/10.1016/S0022-1694(01)00487-5

Kirchner, J.W., Feng, X., Neal, C., 2000. Fractal stream chemistry and its implications for contaminant transport in catchments. Nature 403, 524-527. doi:10.1038/35000537

Laudon, H., Berggren, M., Ågren, A., Buffam, I., Bishop, K., Grabs, T., Jansson, M., Köhler, S., 2011. Patterns and Dynamics of Dissolved Organic Carbon (DOC) in Boreal Streams: The Role of Processes, Connectivity, and Scaling. Ecosystems 14, 880-893. doi:10.1007/s10021-011-9452-8

Laudon, H., Taberman, I., Ågren, A., Futter, M., Ottosson-Löfvenius, M., Bishop, K., 2013. The Krycklan Catchment Study-A flagship infrastructure for hydrology, biogeochemistry, and climate research in the boreal landscape. Water Resour. Res. 49, 7154-7158. doi:10.1002/wrcr.20520 
Leray, S., Dreuzy, J.-R. de, Bour, O., Labasque, T., Aquilina, L., 2012. Contribution of age data to the characterization of complex aquifers. J. Hydrol. 464-465, $54-68$. doi:http://dx.doi.org/10.1016/j.jhydrol.2012.06.052

Likens, G.E., 2013. The Hubbard Brook Ecosystem Study: Celebrating 50 Years. Bull. Ecol. Soc. Am. 94, 336-337. doi:10.1890/0012-9623-94.4.336

Maher, K., 2011. The role of fluid residence time and topographic scales in determining chemical fluxes from landscapes. Earth Planet. Sci. Lett. 312, 48 - 58. doi:http://dx.doi.org/10.1016/j.epsl.2011.09.040

Maloszewski, P., Zuber, A., 1996. Lumped parameter models for the interpretation of environmental tracer data.

McDonnell, J.J., Beven, K., 2014. Debates :The future of hydrological sciences: A (common) path forward? A call to action aimed at understanding velocities, celerities and residence time distributions of the headwater hydrograph. Water Resour. Res. 50, $5342-5350$.

McDonnell, J., Rowe, L., Stewart, M., 1999. A combined tracer-hydrometric approach to assess the effect of catchment scale on water flow path, source and age. IAHS-AISH Publ. 265-273.

McGlynn, B., McDonnell, J., Stewart, M., Seibert, J., 2003. On the relationships between catchment scale and streamwater mean residence time. Hydrol. Process. 17, 175-181. doi:10.1002/hyp.5085

McGuire, K.J., DeWalle, D.R., Gburek, W.J., 2002. Evaluation of mean residence time in subsurface waters using oxygen-18 fluctuations during drought conditions in the mid- 
Appalachians. J. Hydrol. 261, 132 - 149. doi:http://dx.doi.org/10.1016/S00221694(02)00006-9

McGuire, K.J., McDonnell, J.J., 2006. A review and evaluation of catchment transit time $\begin{array}{llllll}\text { modeling. } & \text { J. } & \text { Hydrol. } & 330, & 543 & -\end{array}$ doi:http://dx.doi.org/10.1016/j.jhydrol.2006.04.020

McGuire, K.J., McDonnell, J.J., Weiler, M., Kendall, C., McGlynn, B.L., Welker, J.M., Seibert, J., 2005. The role of topography on catchment-scale water residence time. Water Resour. Res. 41, n/a-n/a. doi:10.1029/2004WR003657

Moldan, B., Černỳ, J., 1994. Small catchment research, in: Biogeochemistry of Small Catchments, a Tool for Environmental Research. John Wiley \& Sons, pp. 1-30.

Montgomery, D.R., Dietrich, W.E., 1989. Source areas, drainage density, and channel initiation. Water Resour. Res. 25, 1907-1918. doi:10.1029/WR025i008p01907

Morton, D., Bolton, W., Endalamaw, A., Young, J., Hinzman, L., 2014. Hydrological Parameter Estimation (HYPE) System for Bayesian Exploration of Parameter Sensitivities in an Arctic Watershed, in: AGU Fall Meeting Abstracts. p. 02.

Mueller, M.H., Weingartner, R., Alewell, C., 2013. Importance of vegetation, topography and flow paths for water transit times of base flow in alpine headwater catchments. Hydrol. Earth Syst. Sci. 17, 1661-1679. doi:10.5194/hess-17-1661-2013

Ocampo, C.J., Oldham, C.E., Sivapalan, M., 2006. Nitrate attenuation in agricultural catchments: Shifting balances between transport and reaction. Water Resour. Res. 42, n/a-n/a. doi:10.1029/2004WR003773 
Oldham, C.E., Farrow, D.E., Peiffer, S., 2013. A generalized Damköhler number for classifying material processing in hydrological systems. Hydrol. Earth Syst. Sci. 17, 1133-1148. doi:10.5194/hess-17-1133-2013

O'loughlin, E., 1981. Saturation regions in catchments and their relations to soil and topographic properties. J. Hydrol. 53, 229-246.

Pinay, G., Peiffer, S., De Dreuzy, J.-R., Krause, S., Hannah, D., Fleckenstein, J., Sebilo, M., Bishop, K., Hubert-Moy, L., 2015. Upscaling Nitrogen Removal Capacity from Local Hotspots to Low Stream Orders' Drainage Basins. Ecosystems 18, 1101-1120. doi:10.1007/s 10021-015-9878-5

Rinaldo, A., Beven, K.J., Bertuzzo, E., Nicotina, L., Davies, J., Fiori, A., Russo, D., Botter, G., 2011. Catchment travel time distributions and water flow in soils. Water Resour. Res. 47, n/a-n/a. doi:10.1029/2011WR010478

Roa-Garcia, M.C., Weiler, M., 2010. Integrated response and transit time distributions of watersheds by combining hydrograph separation and long-term transit-time modeling. Hydrol. Earth Syst. Sci. 14, 1537.

Rodgers, P., Soulsby, C., Waldron, S., Tetzlaff, D., 2005. Using stable isotope tracers to assess hydrological flow paths, residence times and landscape influences in a nested mesoscale catchment. Hydrol. Earth Syst. Sci. 9, 139-155. doi:10.5194/hess-9-1392005

Rodhe, A., Nyberg, L., Bishop, K., 1996. Transit Times for Water in a Small Till Catchment from a Step Shift in the Oxygen 18 Content of the Water Input. Water Resour. Res. 32, 3497-3511. doi:10.1029/95WR01806 
Scanlon, B., Healy, R., Cook, P., 2002. Choosing appropriate techniques for quantifying groundwater recharge. Hydrogeol. J. 10, 18-39. doi:10.1007/s10040-001-0176-2

Schilling, K.E., Jones, C.S., Seeman, A., 2013. How Paired Is Paired? Comparing Nitrate Concentrations in Three Iowa Drainage Districts. J. Environ. Qual. 42, 1412-1421. doi:10.2134/jeq2013.03.0085.

Schumann, S., Schmalz, B., Meesenburg, H. \& Schröder, U. (eds), 2010. Braunschweig Declaration - The need for a global network of long-term small hydrological research basins, Status and Perspectives of Hydrology in Small Basins. International Association of Hydrological Sciences., pp. 305-307.

Seeger, S., Weiler, M., 2014. Reevaluation of transit time distributions, mean transit times and their relation to catchment topography. Hydrol. Earth Syst. Sci. 18, 4751-4771.

Šimŭnek, J., Jarvis, N.J., Van Genuchten, M.T., Gärdenäs, A., 2003. Review and comparison of models for describing non-equilibrium and preferential flow and transport in the vadose zone. J. Hydrol. 272, 14-35.

Sivapalan, M., 2003. Prediction in ungauged basins: a grand challenge for theoretical hydrology. Hydrol. Process. 17, 3163.

Sophocleous, M., 2002. Interactions between groundwater and surface water: the state of the science. Hydrogeol. J. 10, 52-67. doi:10.1007/s10040-001-0170-8

Soulsby, C., Piegat, K., Seibert, J., Tetzlaff, D., 2011. Catchment-scale estimates of flow path partitioning and water storage based on transit time and runoff modelling. Hydrol. Process. 25, 3960-3976. 
Soulsby, C., Tetzlaff, D., 2008. Towards simple approaches for mean residence time estimation in ungauged basins using tracers and soil distributions. J. Hydrol. 363, 60 74. doi:http://dx.doi.org/10.1016/j.jhydrol.2008.10.001

Swank, W.T., Crossley, D.A.J., 1988. Forest hydrology and ecology at Coweeta. Springer Science \& Business Media.

Tetzlaff, D., Carey, S.K., Laudon, H., McGuire, K., 2010. Catchment processes and heterogeneity at multiple scales-benchmarking observations, conceptualization and prediction. Hydrol. Process. 24, 2203-2208. doi:10.1002/hyp.7784

Tetzlaff, D., McDonnell, J.J., Uhlenbrook, S., McGuire, K.J., Bogaart, P.W., Naef, F., Baird, A.J., Dunn, S.M., Soulsby, C., 2008. Conceptualizing catchment processes: simply too complex? Hydrol. Process. 22, 1727-1730. doi:10.1002/hyp.7069

Tetzlaff, D., Seibert, J., McGuire, K.J., Laudon, H., Burns, D.A., Dunn, S.M., Soulsby, C., 2009a. How does landscape structure influence catchment transit time across different geomorphic provinces? Hydrol. Process. 23, 945-953. doi:10.1002/hyp.7240

Tetzlaff, D., Seibert, J., Soulsby, C., 2009b. Inter-catchment comparison to assess the influence of topography and soils on catchment transit times in a geomorphic province, the Cairngorm Mountains, Scotland. Hydrol. Process. 23, 1874.

Tetzlaff, D., Soulsby, C., Bacon, P.J., Youngson, A.F., Gibbins, C., Malcolm, I.A., 2007. Connectivity between landscapes and riverscapes - a unifying theme in integrating hydrology and ecology in catchment science? Hydrol. Process. 21, 1385-1389. doi:10.1002/hyp.6701 
Thomas, Z., Abbott, B., Troccaz, O., Baudry, J., Pinay, G., 2015. Proximate and ultimate controls on carbon and nutrient dynamics of small agricultural catchments. Biogeosciences Discuss. 12, 15337-15367. doi:10.5194/bgd-12-15337-2015.

Timbe, E., Windhorst, D., Crespo, P., Frede, H., Feyen, J., Breuer, L., 2014. Understanding uncertainties when inferring mean transit times of water trough tracer-based lumpedparameter models in Andean tropical montane cloud forest catchments. Hydrol Earth Syst Sci 18, 1503-1523.

Todini, 2007. Hydrological catchment modeling: past, present and future. Hydrol. Earth Syst. Sci. 11, 468.

Tóth, J., 1962. A theory of groundwater motion in small drainage basins in central Alberta, Canada. J Geophys Res 67, 4375-4387.

Tóth, J., 1963. A theoretical analysis of groundwater flow in small drainage basins. Journal of Geophysical Research, 68(16): 4795-4812.

Turnadge, C., Smerdon, B.D., 2014. A review of methods for modelling environmental tracers in groundwater: Advantages of tracer concentration simulation. J. Hydrol. 519, $3674-3689$.

Van der Velde, Y., Heidbüchel, I., Lyon, S.W., Nyberg, L., Rodhe, A., Bishop, K., Troch, P.A., 2015. Consequences of mixing assumptions for time-variable travel time distributions. Hydrol. Process. 29, 3460-3474. doi:10.1002/hyp.10372

Van der Velde, Y., Torfs, P.J.J.F., van der Zee, S.E.A.T.M., Uijlenhoet, R., 2012. Quantifying catchment-scale mixing and its effect on time-varying travel time distributions. Water Resour. Res. 48, n/a-n/a. doi:10.1029/2011WR011310 
Vitvar, T., Balderer, W., 1998. Estimation of mean residence times and runoff generation by stable isotope measurements in a small prealpine catchments. Appl. Geochem. 12, 787-796.

Viville, D., Ladouche, B., Bariac, T., 2006. Isotope hydrological study of mean transit time in the granitic Strengbach catchment (Vosges massif, France): application of the FlowPC model with modified input function. Hydrol. Process. 20, 1737-1751. doi:10.1002/hyp.5950

Voeckler, H.M., Allen, D.M., Alila, Y., 2014. Modeling coupled surface water - Groundwater processes in a small mountainous headwater catchment. J. Hydrol. 517, 1089 - 1106. doi:http://dx.doi.org/10.1016/j.jhydrol.2014.06.015

Winter, T.C., 1999. Relation of streams, lakes, and wetlands to groundwater flow systems. Hydrogeol. J. 7, 28-45. doi:10.1007/s100400050178

Wolock D.M, Fan J, Lawrence G.B, 1997. Effects of basin size on low-flow stream chemistry and subsurface contact time in the Neversink River watershed, New York. Hydrol. Process. 11, 1273. 


\section{Figures}

Figure 1: Controls on hydrological functioning at the catchment scale. This conceptual model highlights the physical, biological, and anthropogenic processes and spatial and temporal scales that underlie the regulating and driving (forcing) factors that can differ between catchments. Quantifying the relative importance of these factors in multiple environments is key to generating general understanding of catchment hydrology and biogeochemistry.

Figure 2: Organizational schema and justification for the Catchment virtual Observatory for Sharing flow and transport models outputs (COnSOrT). Metadata, model outputs, and postprocessing techniques will be available through COnSOrT.

Figure 3: Topographical and geological layers of the example catchment in western France in the Zone Atelier Armorique where which particle tracking and time distributions have been analysed (Thomas et al., 2015).

Figure 4: Pathlines from FEFLOW simulation obtained using a forward particle tracking method. The colours indicate the time since the water reached the water table and the line indicate the path followed by a particle. The land surface is superimpose on the top of the pathlines, showing flowpath convergence in topographical lowpoints.

Figure 5: The residence time histogram for the whole catchment indicates that short (on the order of days) and long (on the order of several decades) residence times occur in this catchment.

\section{Tables}

Table 1: Example of Metadata available from the platform. 


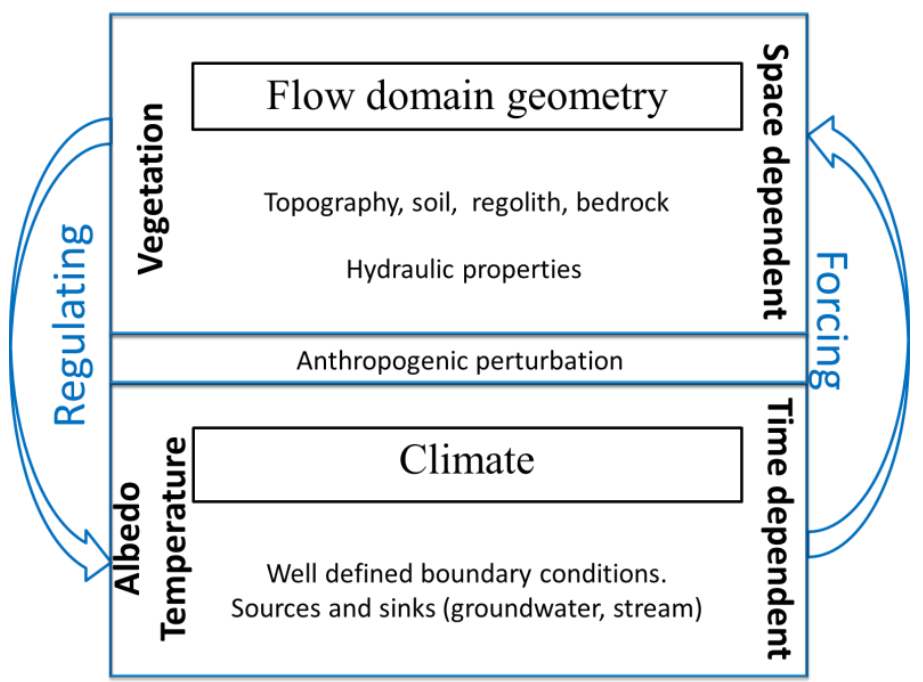




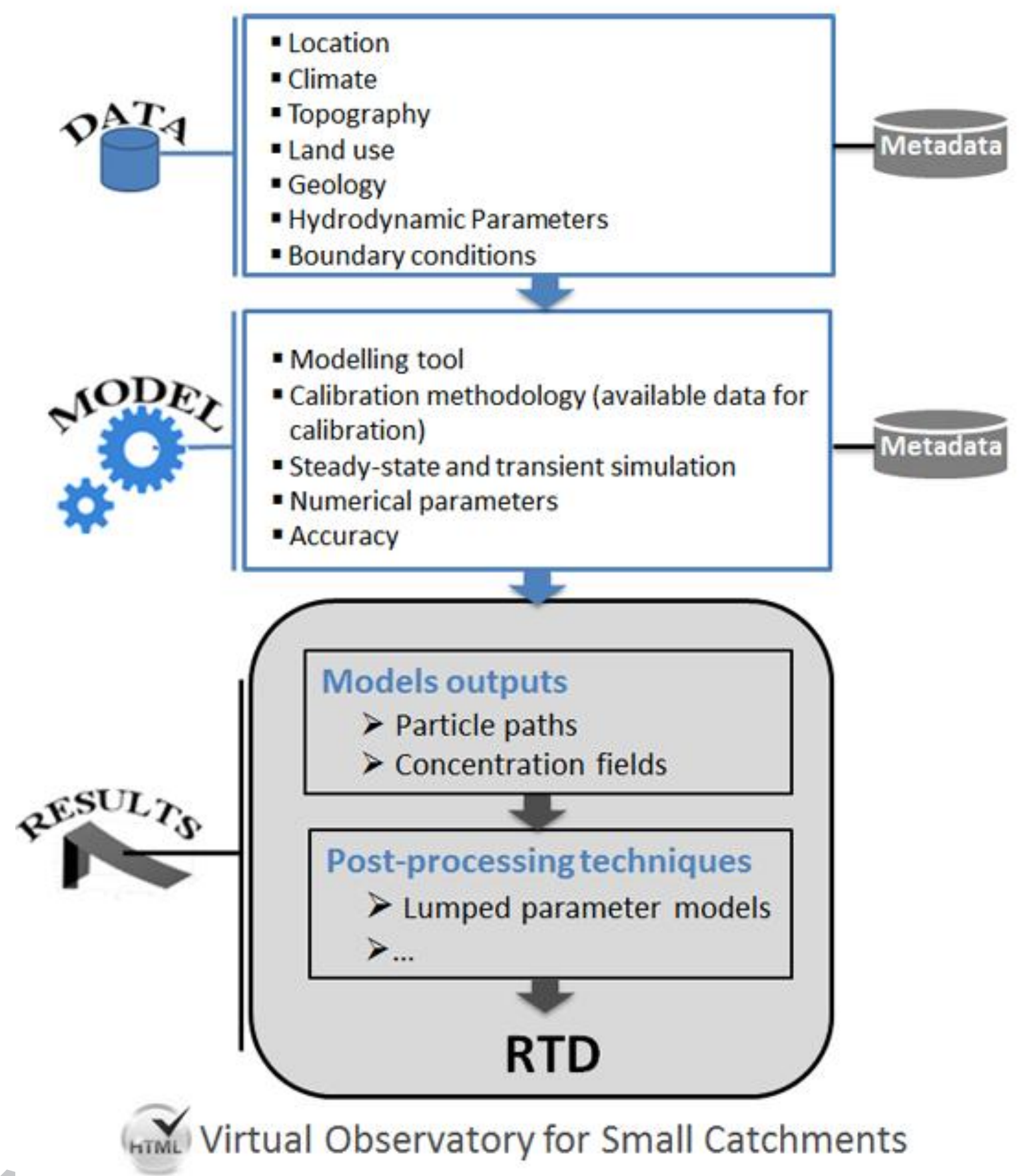




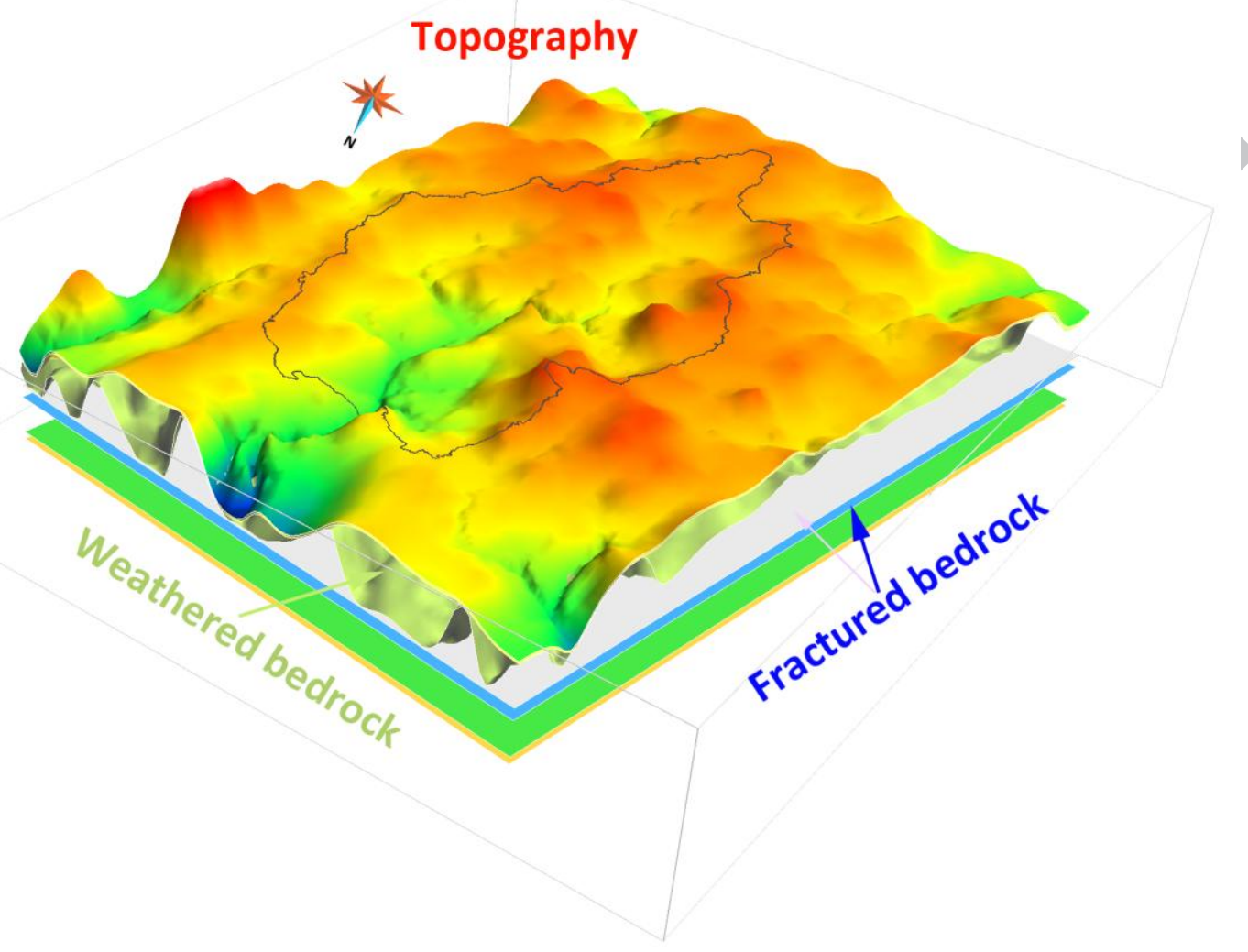




\section{ACCEPTED MANUSCRIPT}

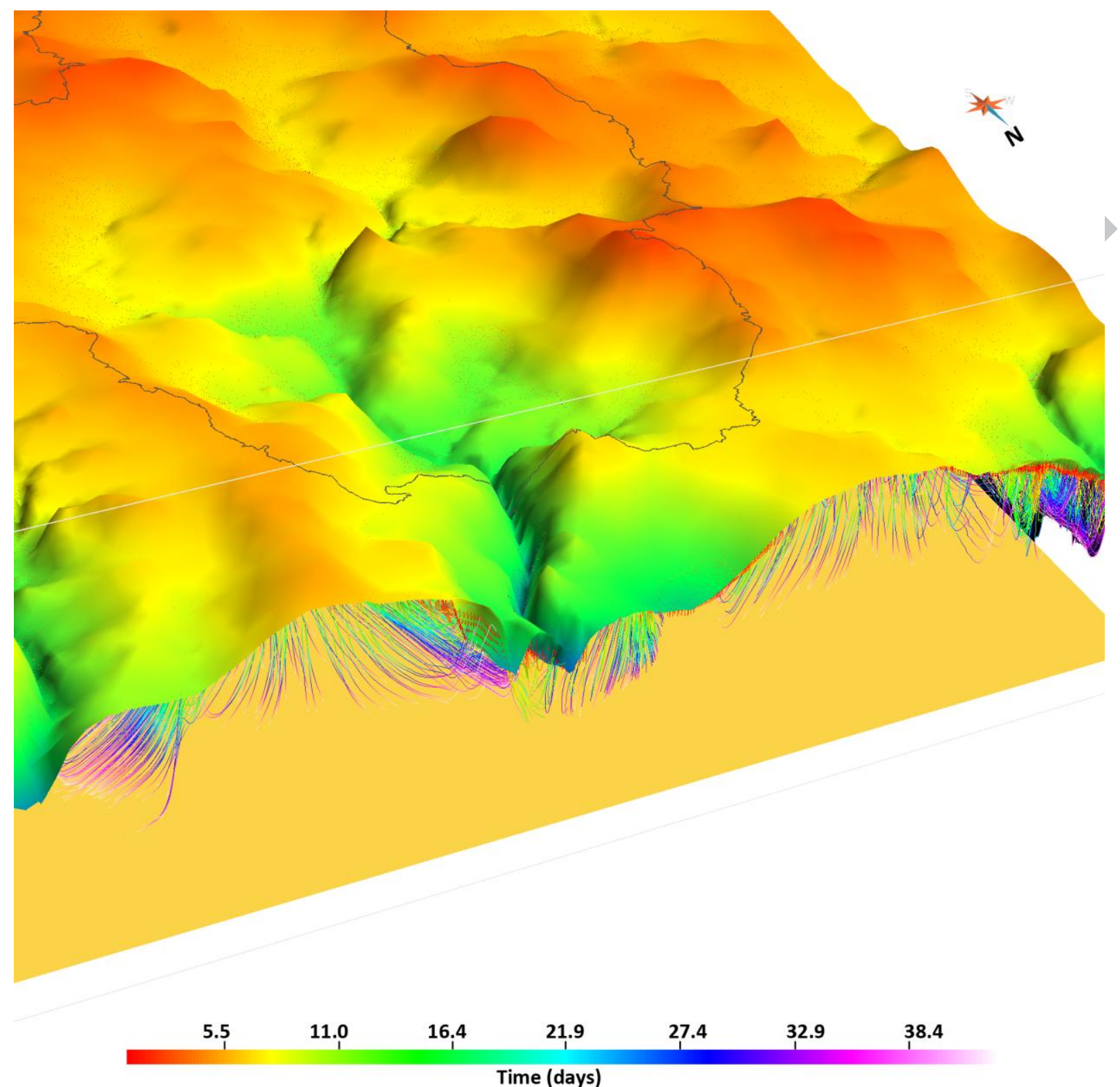


RTD

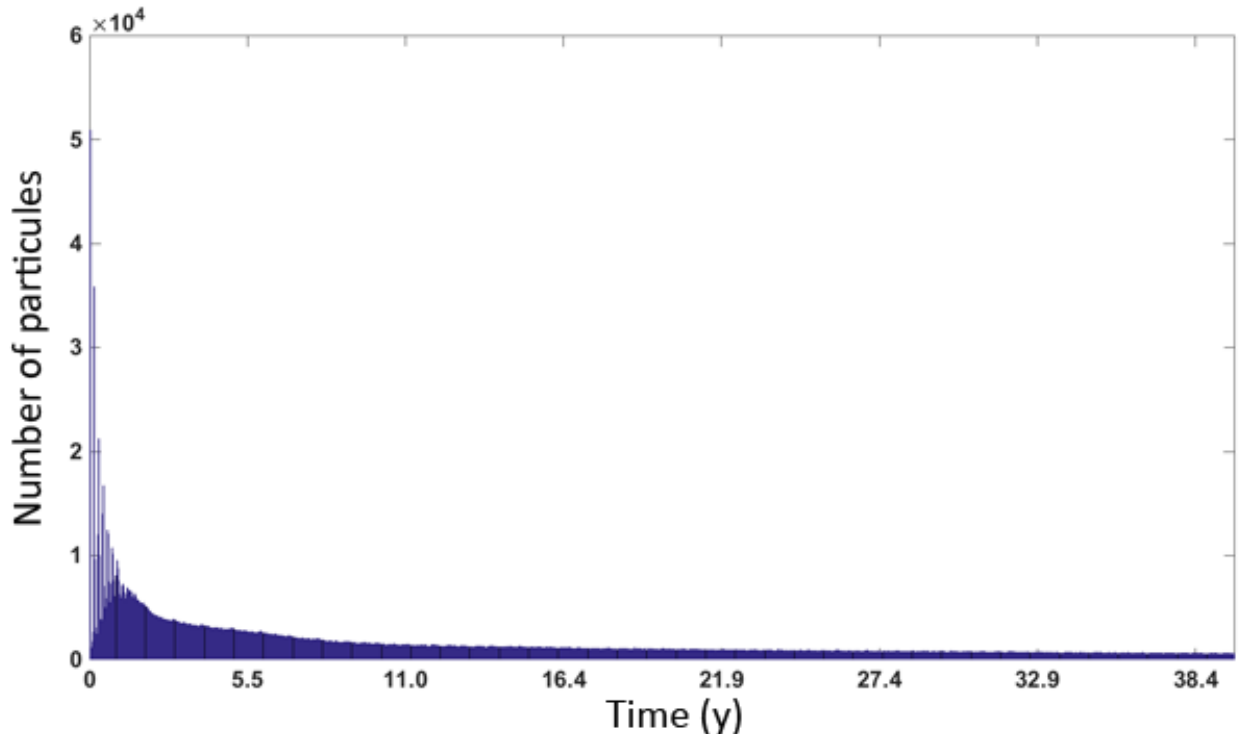




\section{Tables}

Table 1: Example of Metadata available from the platform.

\begin{tabular}{|c|c|c|}
\hline Location & $\begin{array}{l}\text { Name } \\
\text { Country }\end{array}$ & $\begin{array}{c}\text { Zone Atelier Armorique } \\
\text { France }\end{array}$ \\
\hline & $\begin{array}{l}\text { Basin name } \\
\text { Sub-catchment }\end{array}$ & $\begin{array}{l}\text { Le Guyoult } \\
\text { G-01 }\end{array}$ \\
\hline & Outlet Coordinates (WGS84) & $48.48,-1.63$ \\
\hline \multirow[t]{3}{*}{ Topography } & Upstream Elevation (m) & 110.0 \\
\hline & Downstream Elevation (m) & 85.0 \\
\hline & Difference in elevation $(\mathrm{m})$ & 25.0 \\
\hline \multirow[t]{2}{*}{ Soil } & Type & Silty clay \\
\hline & Depth (m) & $\geq 0.8$ \\
\hline \multirow[t]{2}{*}{ Bedrock } & Granite (\% of area) & 100.0 \\
\hline & Schist (\% of area) & 0.0 \\
\hline \multirow[t]{2}{*}{ Hydrology } & Drainage area $\left(\mathrm{km}^{2}\right)$ & 6.4 \\
\hline & Stream order at the outlet & 2.0 \\
\hline $\begin{array}{l}\text { Vegetation } \\
\text { characteristics }\end{array}$ & Hedgerow Density $\left(\mathrm{m} \cdot \mathrm{ha}^{-1}\right)$ & 104.7 \\
\hline Contacts & $\begin{array}{l}\text { zthomas@ agrocampus- } \\
\text { ouest.fr }\end{array}$ & \\
\hline
\end{tabular}




\section{Highlights of the paper "Constitution of a catchment virtual observatory for sharing} flow and transport models outputs"

- A virtual observatory to enhance inter-catchment comparison over a wide range of catchment environments.

- A small catchment virtual observatory to share new approaches and post-processing methods to interpret modelled data.

- The virtual observatory will contribute to the testing and development of new and existing theoretical models in the goal of improving ungauged basin assessments.

- Such observatory will help both modelers and field hydrologists to highlight the main controls on catchments vulnerability and to improve methods to assess ungauged catchment behaviors. 